Glosy Studia luridica Lublinensia vol. XXVI, 2, 2017 DOI: $10.17951 /$ sil.2017.26.2.169

\title{
Paulina Chmielnicka
}

Okręgowa Izba Radców Prawnych w Lublinie pchmielnicka@gmail.com

\section{Glosa do wyroku Sądu Najwyższego z dnia 18 marca 2014 r., I CSK 295/13, dotycząca obniżenia odszkodowania należnego małoletniemu}

\author{
The Commentary on the Supreme Court's Judgment \\ of 18 March 2014, I CSK 295/13, Concerning \\ a Reduction of Compensation Due to the Minor
}

\section{STRESZCZENIE}

Glosa dotyczy problemu oceny, w jakiej sytuacji zachodzą przesłanki warunkujące obniżenie odszkodowania należnego małoletniemu, który przyczynił się do powstania szkody, a ze względu na swój wiek nie ponosi odpowiedzialności, oraz czy można, gdy wymagają tego zasady współżycia społecznego, stosować przez analogię art. 428 k.c. Autorka podziela pogląd SN, że w sytuacji faktycznej przedmiotowej sprawy można stosować przez analogię wspomniany przepis. małoletni

Słowa kluczowe: przyczynienie się poszkodowanego; odszkodowanie; zadośćuczynienie;

Do obniżenia na podstawie art. 362 k.c. odszkodowania należnego małoletniemu, który ze względu na wiek nie ponosi odpowiedzialności, można gdy wymagają tego zasady współżycia społecznego - stosować przez analogię art. 428 k.c.

$$
* * *
$$

Glosowany wyrok został wydany w związku z kasacją złożoną przez powódkę od wyroku Sądu Apelacyjnego z dnia 10 stycznia 2013 r., który uwzględniając apelację w części, zmienił wyrok Sądu Okręgowego przez obniżenie zasądzo- 
nych na rzecz powódki kwot z tytułu zadośćuczynienia, skapitalizowanej i bieżącej renty oraz odszkodowania.

Zasadniczym problemem, przed którym stanął Sąd Najwyższy, było ustalenie, w jaki sposób, na podstawie art. 362 Kodeksu cywilnego ${ }^{1}$, przyczynienie się małoletniego poszkodowanego do powstałej szkody może wpłynąć na zmniejszenie odszkodowania oraz czy można, gdy wymagają tego zasady współżycia społecznego, stosować przez analogię art. 428 k.c. Sąd Najwyższy słusznie uznał, że stosowanie analogii w sprawie będącej przedmiotem rozstrzygnięcia jest dopuszczalne.

Przyjęty w glosowanym wyroku sposób argumentacji, mając na uwadze szczególne okoliczności przedmiotowej sprawy, zasługuje na aprobatę. Problem ten był już kilkakrotnie podejmowany przez Sąd Najwyższy, w związku z czym wykształciła się linia orzecznicza zwalniająca w większości przypadków sądy od obowiązku zmniejszenia odszkodowania, z uwzględnieniem stopnia przyczynienia się poszkodowanego do powstałej szkody. Przedmiotem niniejszej glosy jest wyłącznie ocena przedmiotowego wyroku na płaszczyźnie zagadnień dotyczących przyczynienia się poszkodowanego do powstania lub zwiększenia szkody.

Sprawa rozpatrywana przez sąd dotyczyła zdarzenia zaistniałego 25 maja 2007 r., kiedy małoletnia wówczas powódka, wskutek przechodzenia przez jezdnię w miejscu niedozwolonym, uległa wypadkowi komunikacyjnemu spowodowanemu przez nadjeżdżającego z nadmierną prędkością motocyklistę. Jak wynika z ustaleń poczynionych przez Sąd Okręgowy, bezpośrednią przyczyną zdarzenia było nieprawidłowe zachowanie powódki, natomiast zachowanie kierującego motocyklem istotnie przyczyniło się do powstania wypadku z powodu znacznego przekroczenia dopuszczalnej prędkości. Kierujący poruszał się bowiem z szybkością $97 \mathrm{~km} / \mathrm{h}$, przekraczając tym samym dozwoloną prędkość o $47 \mathrm{~km} / \mathrm{h}$. Ponadto motocyklista przemieszczał się w sposób godzący w zasady ruchu drogowego przez jazdę po niewłaściwym pasie dwujezdniowej drogi. Kierujący motocyklem w chwili wypadku miał 27 lat, powódka zaś - 11 lat. Na skutek zdarzenia małoletnia powódka uległa licznym obrażeniom ciała, w związku z którymi była długo hospitalizowana, poddawana licznym zabiegom operacyjnym. Następstwa zdarzenia towarzyszyć jej będą do końca życia, ponieważ powrót do pełnej sprawności nie będzie możliwy.

Mając na względzie powyższe, Sąd Okręgowy przyznał powódce zadośćuczynienie, obciążając w określonej części pozwanego. W orzeczeniu nie zostały uwzględnione zarzuty pozwanego w kwestii przyczynienia się powódki w $40 \%$ do powstania szkody. Zdaniem sądu nie można było przypisać powódce winy w przedmiotowej sprawie. Wspomniany wyrok Sądu Okręgowego został zmie-

${ }^{1}$ Ustawa z dnia 23 kwietnia 1964 r. - Kodeks cywilny (t.j. Dz.U. z 1964 r., nr 16, poz. 93), dalej jako: k.c. 
niony wyrokiem Sądu Apelacyjnego, który uwzględniając apelację, odpowiednio obniżył zasądzone na rzecz powódki kwoty ze wszystkich tytułów. Zmiana ta została dokonana na skutek oceny, iż powódka przyczyniła się do powstania szkody w 20\%. Następnie, wskutek złożonej przez powódkę skargi kasacyjnej, Sąd Najwyższy orzekł o uchyleniu zaskarżonego wyroku i przekazaniu Sądowi Apelacyjnemu do ponownego rozpoznania, nie podzielając tym samym argumentacji sądu niższej instancji.

Istota problemu poruszanego $\mathrm{w}$ glosowanym orzeczeniu sprowadza się do kwestii przyczynienia się poszkodowanego do powstania lub zwiększenia szkody oraz faktu rozróżnienia samego przyczynienia się od przyczynienia, które może uzasadniać zmniejszenie odszkodowania. Obciążenie poszkodowanego częścią doznanego przez niego uszczerbku w przypadku, gdy pozostaje on w relacji kauzalnej z jego zachowaniem, stanowi wyraz idei, zgodnie z którą każdy ponosi konsekwencje własnych zachowań ${ }^{2}$. Ocenę wyroku należy poprzedzić pewnymi uwagami o charakterze ogólnym. Na samym wstępie warto, w oparciu o art. 362 k.c., przyjrzeć się bliżej samej konstrukcji prawnej przyczynienia się poszkodowanego. Przepis ten należy rozpatrywać w związku z art. 361 k.c., stanowiącym o kwestii ponoszenia odpowiedzialności wyłącznie za normalne następstwa działania lub zaniechania, z którego szkoda wynikła. Samo odszkodowanie zaś powinno w swoich granicach objąć zarówno poniesione przez poszkodowanego straty, jak i możliwe, przyszłe korzyści, które mogły być osiągnięte. Mając na uwadze powyższe, przyczynieniem się poszkodowanego będzie każde jego zachowanie pozostające w normalnym związku przyczynowym ze szkodą wyrządzoną przez inną osobę.

Zwrot ,przyczynił się”, użyty w art. 362 k.c., wywołuje w piśmiennictwie liczne kontrowersje, które wiążą się z faktem różnorakiego rozumienia wspomnianego określenia.

W szeroko pojętej doktrynie wyróżnia się cztery podstawowe rozumienia pojęcia przyczynienia poszkodowanego. Pierwsza koncepcja wskazuje, że chodzi o zachowanie poszkodowanego pozostające $\mathrm{w}$ adekwatnym związku przyczynowym z powstałą szkodą, za którą ponosi odpowiedzialność inna osoba ${ }^{3}$. Kolejny pogląd uznaje wcześniejszą koncepcję za niezupełną, nakazując uzupełniać ją o przesłankę obiektywnej nieprawidłowości zachowania poszkodowanego. Trzecia z kolei uzupełnia dwie poprzednie o konieczność istnienia winy poszkodowanego, a nie jedynie przeświadczenie o obiektywnej nieprawidłowości jego zachowania. Ostatni pogląd wskazuje, iż zachowanie się poszkodowanego może być uznane za jego przyczynienie się do powstania lub zwiększenia szkody, jeżeli po-

${ }^{2}$ Zob. M. Kaliński, [w:] Prawo zobowiąańn-część ogólna, red. A. Olejniczak, Warszawa 2014, s. 193.

${ }^{3}$ Zob. Z. Radwański, A. Olejniczak, Zobowiązania - część ogólna, Warszawa 2012, s. 98. 
zostaje w związku przyczynowym ze szkodą i jest nadto zawinione w przypadkach odpowiedzialności na zasadzie winy, a obiektywnie nieprawidłowe przy odpowiedzialności na zasadzie ryzyka.

W orzecznictwie Sądu Najwyższego za dominującą uznaje się drugą koncepcję. Taki kierunek interpretacji nie powinien budzić wątpliwości, biorąc pod uwagę przyjęcie założenia, że w odróżnieniu od zachowania o znamionach obiektywnej nieprawidłowości, postępowanie prawidłowe nie może pociągać za sobą powstania szkody jako normalnego skutku ${ }^{4}$. Istotne w omawianym przypadku jest także wskazanie postaci przyczynienia się poszkodowanego. Może ono bowiem polegać na przyczynieniu się zarówno do powstania szkody, jak i do jej zwiększenia. Jeżeli zachowanie poszkodowanego współistnieje od początku z przyczyną, za którą odpowiada dłużnik, wówczas poszkodowany przyczynia się do powstania szkody ${ }^{5}$. Natomiast przyczynia się do jej zwiększenia, jeżeli ponosząc już uszczerbek, za który odpowiada dłużnik, poszkodowany podejmuje działania lub zaniechania wpływające na wielkość szkody w ten sposób, że ich brak byłby równoznaczny z mniejszym rozmiarem uszczerbku niż ten, jakiego doznał.

W przedmiotowej sprawie poszkodowana niewątpliwie przyczyniła się do powstania szkody. Zachowanie małoletniej pozostaje w adekwatnym związku przyczynowym do powstałej wskutek jej zachowania szkody. W tym miejscu jednak należy postawić sobie pytanie, czy przyczynienie się poszkodowanej, jakie miało miejsce w omawianej sprawie, uzasadnia obniżenie odszkodowania. Mając na względzie obiektywne przesłanki, a mianowicie fakt, iż poszkodowana w chwili zdarzenia była małoletnia, nie można przypisać jej winy. Idąc natomiast za literalnym brzmieniem art. 362 k.c., obowiązek naprawienia szkody ulega odpowiedniemu zmniejszeniu stosownie do okoliczności, a zwłaszcza do stopnia winy obu stron. Jak trafnie wskazał Sąd Najwyższy, fakt, że z powodu wieku poszkodowanego nie można przypisać winy, nie wyłącza możliwości kwalifikowania jego zachowania pod kątem nieprawidłowości.

W piśmiennictwie przyjmuje się, że art. 362 k.c. zawiera normę kompetencyjną stanowiącą wyraz zasady sędziowskiego wymiaru odszkodowania, zgodnie z którą sąd stosownie do okoliczności sprawy decyduje o obowiązku stosownego zmniejszenia odszkodowania w zależności od stopnia przyczynienia się poszkodowanego do powstania szkody. Decyzja ta jest jego uprawnieniem, wpływ na nią mają zaś wszystkie przesłanki o charakterze obiektywnym i subiektywnym. W judykaturze utrwaliło się, że przyczynienie się poszkodowanego jest jedynie

\footnotetext{
${ }^{4}$ Por. uchwała SN 7 sędziów - zasada prawna z dnia 20 września 1975 r., III CZP 8/75, LEX nr 1947.

${ }^{5}$ Zob. A. Olejniczak, [w:] Kodeks cywilny. Komentarz, t. 3: Zobowiazania - część ogólna, red.
} A. Kidyba, Warszawa 2014, s. 231. 
warunkiem wstępnym miarkowania odszkodowania ${ }^{6}$. Ponadto okoliczności, które wpływają na stopień przyczynienia się, nie mogą być utożsamiane z okolicznościami usprawiedliwiającymi zmniejszenie odszkodowania. O tym, czy zachowanie poszkodowanego stanowiło współprzyczynę szkody odpowiadającej cechom normalnego związku przyczynowego, decyduje ocena konkretnych okoliczności sprawy, uwzględniając przy tym zasady doświadczenia życiowego. W przypadku sprawy będącej przedmiotem glosowanego wyroku sąd wziął pod uwagę szczególne okoliczności, jakie towarzyszyły zdarzeniu. Poszkodowanej przechodzącej w miejscu niedozwolonym towarzyszyła matka, w związku z czym można przypuszczać, że jej zachowanie uwarunkowane było bezpośrednio postępowaniem matki jako swoistemu autorytetowi poszkodowanej ${ }^{7}$.

Ocena stanu faktycznego nie była przedmiotem glosowanego wyroku z racji zasad kognicji Sądu Najwyższego, jednakże biorąc pod uwagę okoliczności sprawy oraz zasady, jakim towarzyszy ustalenie przesłanek przyczynienia się poszkodowanego do powstałej szkody, przybliżenie kontekstu sytuacyjnego zdarzenia może okazać się niezbędne.

Wcześniejsze orzecznictwo Sądu Najwyższego wskazywało, że w sytuacjach, gdy do powstania szkody przyczynił się małoletni poszkodowany, obowiązek jej naprawienia może zostać zmniejszony stosownie do okoliczności, do których wobec wyłączenia winy zalicza się ocenę zachowania dziecka według miernika obiektywnej prawidłowości zachowania ${ }^{8}$. Ocena taka jest o tyle trudna, że ciężko jest przewidzieć, jak w takiej sytuacji może zachować się małoletni, tym bardziej że świadomość w samodzielnym poruszaniu się zgodnie z zasadami ruchu drogowego jest kwestią indywidualną i zależy od stopnia dojrzałości małoletniego. W przedmiotowej sprawie istotne znaczenie ma fakt niesamodzielnego podjęcia decyzji o przejściu przez jezdnię w miejscu niedozwolonym. Wobec braku opinii psychologa dotyczącej poszkodowanej nie można określić, czy była zdolna

${ }^{6}$ Zob. wyrok SN z dnia 12 lipca 2012 r., I CSK 660/11, LEX nr 1228769; wyrok SN z dnia 19 listopada 2009 r., IV CSK 241/09, LEX nr 677896; wyrok SA w Łodzi z dnia 27 lutego 2015 r., I ACa 1280/14, LEX nr 1665832.

${ }^{7} \mathrm{~W}$ judykaturze pojawił się pogląd, jakoby skutki przyczynienia się rodziców do powstania szkody, która dotknęła ich małoletnie dziecko, są równoznaczne - jeśli chodzi o konsekwencje określone w art. 362 - z przyczynieniem się samego poszkodowanego. Zob. wyrok SN z dnia 2 grudnia 1982 r., IV CR 484/82, LEX nr 5174. Pogląd ten spotkał się z uzasadnioną krytyką, której odzwierciedlenie znalazło wyraz w wyroku SN z dnia 16 marca 1983 r., I CR 33/83, LEX nr 2898.

${ }^{8}$ Por. wyrok SN z dnia 29 października 2008 r., IV CSK 228/08, LEX nr 513257. Sąd Najwyższy w powołanym wyroku rozstrzygał sprawę dotyczącą małoletniego, który wtargnął na jezdnię, wskutek czego został potrącony przez nadjeżdżający samochód. Jego zachowanie było obiektywnie nieprawidłowe, niezgodne z zasadami korzystania $\mathrm{z}$ drogi przez pieszych i w istotnym zakresie doprowadziło do powstania szkody. Sąd, uwzględniając wiek powoda, który w chwili zdarzenia miał 3,5 roku, uznał, że zmniejszenie zadośćuczynienia na podstawie art. 362 k.c. nie może nastąpić w takim zakresie, jaki byłby właściwy wobec osoby dorosłej, która zachowałaby się w podobny sposób na drodze. 
do oceny niebezpieczeństwa związanego z postępowaniem na drodze. W związku z powyższym stosowanie uogólnienia, że mając 11 lat, małoletni zasadniczo zdaje sobie sprawę z konsekwencji swojego zachowania, mogłoby w omawianej sprawie okazać się krzywdzące i niezgodne z prawdą.

Ponadto na rozmiar szkody wpływ miało zachowanie motocyklisty będącego sprawcą tragicznego zdarzenia. Zgodnie $\mathrm{z}$ ustaleniami poczynionymi przez biegłego jego zachowanie odbiegało od norm przewidzianych w przepisach prawa o ruchu drogowym. Przekraczając prędkość oraz jadąc po niewłaściwym pasie ruchu, przyczynił się w istotny sposób do zdarzenia. Kierujący motocyklem w chwili zdarzenia miał 27 lat, co - jak słusznie przyjął sąd - obligowało go do zachowywania szczególnej ostrożności, zwłaszcza widząc dziecko przechodzące przez jezdnię. Mając na względzie powyższe, sąd właściwie wskazał, że zmniejszenie obowiązku naprawienia szkody może pozostawać w sprzeczności z zasadami współżycia społecznego. W art. 362 k.c. brak jest wzmianki na temat odwołania do wspomnianej klauzuli generalnej, jednakże sąd trafnie odwołał się w drodze analogii do art. 428 k.c. Przepis ten opiera się bowiem na podobnej sytuacji, a mianowicie okolicznościach dotyczących zdarzenia z udziałem małoletniego.

Dokonując analizy judykatury dotyczącej problematyki przyczynienia się poszkodowanego do powstałej szkody, można wysnuć tezę, iż sądy w przypadku zdarzeń dotyczących małoletnich poszkodowanych najczęściej rezygnują z obniżenia odszkodowania, traktując art. 362 k.c. jako przejaw swobodnego uznania sądu w konkretnych okolicznościach ${ }^{9}$. Jest to stanowisko zrozumiałe, biorąc pod uwagę fakt, iż w przypadku zdarzeń z udziałem dzieci szkody, jakich doznają, są zdecydowanie większe i najczęściej powodują tragiczne skutki, które mają wpływ na dalsze życie, wykluczając poszkodowanych z normalnego funkcjonowania.

W opisywanych okolicznościach względy słuszności i przytaczane zasady współżycia społecznego nakazują powstrzymanie się od obniżania odszkodowania należnego poszkodowanemu. Trafne zdaje się przyjęcie stanowiska, iż art. 362 k.c. jest wyrazem zasady sędziowskiego swobodnego uznania i wymiaru odszkodowania. Odstąpienie od obniżenia odszkodowania powinno być uzasadnione szczególnymi okolicznościami towarzyszącymi kwestii będącej przedmiotem rozważań sądu. W związku z powyższym Sąd Najwyższy zajął trafne stanowisko, oddając sprawę sądowi niższej instancji do ponownego rozpoznania. Argumentacja sądu, mając na względzie powyższe ustalenia, zasługuje na pełną aprobatę.

${ }^{9}$ Zob. wyrok SA w Łodzi z dnia 25 sierpnia 2015 r., I ACa 230/15, LEX nr 1808682; wyrok SN z dnia 2 sierpnia 2006 r., IV CSK 118/06, LEX nr 369169. 
Pobrane z czasopisma Studia Iuridica Lublinensia http://studiaiuridica.umes.pl Data: 26/04/2023 14:00:50

Glosa do wyroku Sądu Najwyższego z dnia 18 marca 2014 r., I CSK 295/13...

\section{BIBLIOGRAFIA}

Kaliński M., [w:] Prawo zobowiazań - część ogólna, red. A. Olejniczak, Warszawa 2014.

Olejniczak A., [w:] Kodeks cywilny. Komentarz, t. 3: Zobowiązania-część ogólna, red. A. Kidyba, Warszawa 2014.

Radwański Z., Olejniczak A., Zobowiązania - część ogólna, Warszawa 2012.

Uchwała SN 7 sędziów - zasada prawna z dnia 20 września 1975 r., III CZP 8/75, LEX nr 1947.

Ustawa z dnia 23 kwietnia 1964 r. - Kodeks cywilny (t.j. Dz.U. z 1964 r., nr 16, poz. 93).

Wyrok SA w Łodzi z dnia 27 lutego 2015 r., I ACa 1280/14, LEX nr 1665832.

Wyrok SA w Łodzi z dnia 25 sierpnia 2015 r., I ACa 230/15, LEX nr 1808682.

Wyrok SN z dnia 2 grudnia 1982 r., IV CR 484/82, LEX nr 5174.

Wyrok SN z dnia 16 marca 1983 r., I CR 33/83, LEX nr 2898.

Wyrok SN z dnia 2 sierpnia 2006 r., IV CSK 118/06, LEX nr 369169.

Wyrok SN z dnia 29 października 2008 r., IV CSK 228/08, LEX nr 513257.

Wyrok SN z dnia 19 listopada 2009 r., IV CSK 241/09, LEX nr 677896.

Wyrok SN z dnia 12 lipca 2012 r., I CSK 660/11, LEX nr 1228769.

\section{SUMMARY}

This commentary refers to the assessment of the situation in which there are grounds conditioning the reduction of compensation due to an underage, who contributed to the injury, and because of his age is not responsible, and is it possible when required by the principles of community life - to apply by analogy Art. 428 of the Civil Code. The author agrees with the Supreme Court, that in the factual situation of the case it can be applied by analogy with the said provision.

Keywords: reduction of compensation; compensation; remedy; minor 